\title{
Rhizobium strains differ considerably in outer membrane permeability and polymyxin $B$ resistance
}

\author{
Iwona Komaniecka1, Katarzyna Zamłyńska1, Radosław Zan¹, Magdalena Staszczak², Jarosław \\ Pawelec $^{3}$, Irena Seta ${ }^{1}$ and Adam Choma ${ }^{\circledR}$ \\ 1Department of Genetics and Microbiology, ${ }^{2}$ Department of Biochemistry, ${ }^{3}$ Department of Comparative Anatomy and Anthropology, Maria \\ Curie-Sklodowska University, Lublin, Poland
}

Six rhizobium (Rhizobium leguminosarum bv. Trifolii TA1, Sinorhizobium meliloti 1021, Mesorhizobium huakuii IFO 15243', Ochrobactrum lupini LUP 21'T, Bradyrhizobium japonicum USDA110 and B. elkanii USDA 76) and two Escherichia coli strains (E. coli ATCC 25922 and E. coli HB $101)$ were compared in respect to polymyxin $B$ and EDTA resistance, as well as bacterial outer membrane (OM) permeability to a fluorescent hydrophobic agent ( $\mathrm{N}$-phenyl-1-naphthylamine - NPN). TEM (Transmission Electron Microscopy) and a microbial test demonstrated that all the rhizobia were much more resistant to polymyxin $B$ in comparison with $E$. coli strains. EDTA and polymyxin B enhance permeability of $B$. japonicum and O. lupini OM. Other rhizobia incorporated NPN independently of the presence of membrane-deteriorating agents; however, the level of fluorescence (measured as NPN absorption) was strain dependent.

Key words: rhizobium; outer membrane; lipopolysaccharide; N-phenyl-1-naphthylamine, NPN; polymyxin B

Received: 09 November, 2015; revised: 16 February, 2016; accepted: 29 April, 2016; available on-line: 02 June, 2016

\section{INTRODUCTION}

The cell walls of Gram-negative bacteria, including rhizobia, possess characteristic spatial organization which is composed of a cytoplasmic membrane (CM), a periplasmic space where the murein sacculus is located, and an outer membrane $(\mathrm{OM})$. The latter bilayer $(\mathrm{OM})$ mentioned is usually composed of three different types of molecules: phospholipids, peripheral and transmembrane proteins, and a complex glycolipid, called lipopolysaccharide (LPS). The OM has a highly asymmetric structure with phospholipids on the inner leaflet and LPS molecules furnishing the outer part of the bilayer. The OM is a selectively permeable barrier to external matter, and its impermeability to hydrophobic compounds is mainly due to the presence of LPS, occupying the entire outer part of the OM. When phospholipids are present in this leaflet (as observed in the case of certain mutants), the barrier is ineffective (Nikaido, 2003). To facilitate the diffusion of small (about $1500 \mathrm{Da}$ ) molecules across the wall, bacteria incorporate porins into the outer bilayer. Some polycationic compounds (e.g. aminoglycoside antibiotics), along with polycationic detergents (e.g. polymyxin B), can bind to lipid A (a hydrophobic anchor of the LPS) deteriorating the OM barrier and penetrate it in a self-promoted way (Vaara, 1992; Martínez de Tejada et al., 1995; Nikaido, 2003; Mares et al., 2009).
The lipopolysaccharide is typically composed of three domains: lipid A, which constitutes an OM outer leaflet, a short core oligosaccharide, and, very often, an O-specific polysaccharide (O-chain, O-PS). The structures of O-polysaccharides and core oligosaccharides obtained from rhizobial LPS, as well as their functions, are described in detail in review articles by De Castro and co-workers (2008) and Carlson and co-workers (2010).

Enterobacterial lipid A, toxic to humans, consists of a $\beta$ - $(1 \rightarrow 6)$-linked glucosaminyl disaccharide substituted on both sides by phosphate groups. Six fatty acid residues, which form two acyloxyacyl moieties, are linked in distinct positions to the sugar backbone (Zähringer et al., 1999; Raetz \& Whitfield, 2002). Lipids A, the structures of which differ from enterobacterial ones, are not as unusual as it was thought previously. The rhizobial lipid A especially represents a highly structurally diversified group of molecules (De Castro et al., 2008). The backbone of the lipids A can be composed either of a glucosaminyl-(D-Glc $p \mathrm{~N}$ ) (Rhizobium and Sinorbizobium genera) or a 2,3-diamino-2,3-dideoxyglucosyl-(D-Glc $p \mathrm{~N} 3 \mathrm{~N}$ ) disaccharide (Mesorbizobium, Bradyrbizobium, and Azorbizobium genera). Moreover, in the glucosamine-containing lipid A of Rhizobium leguminosarum, the reducing residue is partly oxidized to 2-aminogluconate (Bhat et al., 1994). The sugar backbone of these lipids A can be decorated either by phosphate (Sinorbizobium and Mesorbizobium), uronic acid (Mesorbizobium and Bradyrbizobium), or mannose (Bradyrhizobium) (Gudlavaletti \& Forsberg, 2003; Choma \& Sowinski, 2004; Komaniecka et al., 2010; Komaniecka et al., 2014; Silipo et al., 2014). All amino groups of amino sugars, as well as the C-3 and C-3' positions of D-Glc $p \mathrm{~N}$, are substituted by 3-hydroxy fatty acids. The hydroxyl groups of these primary fatty acids can be further substituted by nonpolar or ( $\omega$-1)-hydroxy very long chain fatty acids (VLCFAs), forming acyloxyacyl moieties (Gil-Serrano et al., 1994; Russa et al., 1995; Que et al., 2000; Choma \& Sowinski, 2004). Among VLCFAs, 27-octacosanoic acid is present in lipid A of all members of Rhizobiales, except for Azorbirobium caulinodans (Bhat et al., 1991a, Bhat et al., 1991b; Choma et al., 2012). Moreover, in bradyrhizobial LPSs, a number of VLCFAs were identified, including straight-, mono-, and dimethyl branched-chain fatty acids containing 26 up to 34 carbons (Choma \& Komaniecka, 2011). In this

e-mail: adam.choma@poczta.umcs.lublin.pl

Abbreviations: EDTA, ethylenediaminetetraacetic acid disodium salt; LPS, lipopolysaccharide; OM, outer membrane; NPN, N-phenyl1-naphthylamine; SDS-PAGE, sodium dodecyl sulphate-polyacrylamide gel electrophoresis; TEM, Transmission Electron Microscopy 
Table 1. Characterization of bacterial strains used in this study

\begin{tabular}{|c|c|c|c|c|c|c|}
\hline No. & Strain & $\begin{array}{l}\text { Host plant and } \\
\text { geographic origin }\end{array}$ & Description & $\begin{array}{l}\text { Source a) and } \\
\text { references }\end{array}$ & $\begin{array}{l}\text { Abbreviation } \\
\text { used in the text }\end{array}$ & $\begin{array}{l}\text { Culture } \\
\text { medium }\end{array}$ \\
\hline 1. & $\begin{array}{l}\text { Escherichia coli ATCC } 25922, \\
\text { (DSM 1103, FDA strain Seattle } \\
\text { 1946) Serotype O6, Biotype } 1\end{array}$ & not applicable & Smooth type of $E$. coli & ATCC, ZGM & $\begin{array}{l}\text { Escherichia coli } \\
\text { ATCC }\end{array}$ & LB \\
\hline 2. & Escherichia coli HB 101 & not applicable & $\begin{array}{l}\text { Rough variant of laborato- } \\
\text { ry strain K12 }\end{array}$ & $\begin{array}{l}\text { laboratory } \\
\text { strain ZGM }\end{array}$ & $\begin{array}{l}\text { Escherichia coli } \\
\text { HB } 101\end{array}$ & LB \\
\hline 3. & Ochrobactrum lupini LUP $21^{\top}$ & $\begin{array}{l}\text { Lupinus albus, } \\
\text { Spain }\end{array}$ & $\begin{array}{l}\text { Known structure of O-cha- } \\
\text { in (Pac et al., 2015) }\end{array}$ & $\begin{array}{l}\text { Spain (Trujillo et } \\
\text { al., 2006) }\end{array}$ & $\begin{array}{l}\text { Ochrobactrum } \\
\text { lupini }\end{array}$ & LPC \\
\hline 4. & $\begin{array}{l}\text { Mesorhizobium huakuii IFO } \\
15243^{\top}\end{array}$ & $\begin{array}{l}\text { Astragallus sini- } \\
\text { cus, China }\end{array}$ & $\begin{array}{l}\text { Known structure of lipid } \\
\text { A and O-chain (Choma \& } \\
\text { Sowinski, 2004; Choma et. } \\
\text { al., 2000) }\end{array}$ & $\begin{array}{l}\text { IFO (Chen et al., } \\
\text { 1991) }\end{array}$ & $\begin{array}{l}\text { Mesorhizobium } \\
\text { huakuii }\end{array}$ & $79 C A$ \\
\hline 5. & $\begin{array}{l}\text { Sinorhizobium meliloti } 1021 \\
\text { (ATCC 51124) }\end{array}$ & $\begin{array}{l}\text { Medicago, Melilo- } \\
\text { tus, Trigonella }\end{array}$ & $\begin{array}{l}\text { Known structure of lipid A } \\
\text { (Gudlavalletti, \& Forsberg, } \\
\text { 2003) }\end{array}$ & $\begin{array}{l}\text { France (Meade } \\
\text { et al., 1982) }\end{array}$ & $\begin{array}{l}\text { Sinorhizobium } \\
\text { meliloti }\end{array}$ & $79 C A$ \\
\hline 6. & $\begin{array}{l}\text { Rhizobium leguminosarum bv. } \\
\text { Trifolii TA1 (ATCC 53912) }\end{array}$ & $\begin{array}{l}\text { Trifolium, Medi- } \\
\text { terranean basin }\end{array}$ & $\begin{array}{l}\text { Known structure of LPS } \\
\text { (Kannenberg \& Carlson, } \\
\text { 2001; Muszynski et al., } \\
\text { 2011) }\end{array}$ & $\begin{array}{l}\text { ZGM } \\
\text { (Triplett, 1988) }\end{array}$ & $\begin{array}{l}\text { Rhizobium legu- } \\
\text { minosarum }\end{array}$ & TY \\
\hline 7. & $\begin{array}{l}\text { Bradyrhizobium japonicum } \\
\text { USDA } 110 \text { (Bradyrhizobium } \\
\text { diazoefficiens USDA 110) }\end{array}$ & Glycine max, USA & $\begin{array}{l}\text { Known structure of lipid A } \\
\text { (Komaniecka et al., 2014) }\end{array}$ & $\begin{array}{l}\text { USDA (Jordan, } \\
\text { 1982; Delamuta } \\
\text { et al., 2013) }\end{array}$ & $\begin{array}{l}\text { Bradyrhizobium } \\
\text { japonicum }\end{array}$ & LPC \\
\hline 8. & $\begin{array}{l}\text { Bradyrhizobium elkanii USDA } \\
76\end{array}$ & Glycine max, USA & $\begin{array}{l}\text { Known structure of lipid A } \\
\text { (Komaniecka et al., 2010) }\end{array}$ & $\begin{array}{l}\text { USDA (Kuyken- } \\
\text { dall et al., 1992) }\end{array}$ & $\begin{array}{l}\text { Bradyrhizobium } \\
\text { elkanii }\end{array}$ & LPC \\
\hline
\end{tabular}

aATCC, American Type Culture Collection; ZGM, Department of Genetics and Microbiology, Maria Curie-Sklodowska University in Lublin, Poland; IFO, Institute for Fermentation, Osaka, Japan; USDA - United States Department of Agriculture, Beltsville, Md.

group of bacteria, primary fatty acids are substituted by at least two or even three VLCFAs. Additionally, in some bradyrhizobial strains, 3-hydroxybutyric acid can be linked to the $(\omega-1)$ hydroxyl of the VLCFAs. Also, hopanoid compounds seem to be inseparable elements of this class of lipids A (Komaniecka et al., 2010; Komaniecka et al., 2014; Silipo et. al. 2014).

It has been hypothesized that the presence of VLCFAs in rhizobia, and especially the presence of hopanoids in Bradyrbizobium, lipids A are necessary for maintaining the stability of the bacterial OM during the endocytotic invasion process and also for survival of the bacteria within the symbiosomes (Silipo et al., 2014). The alkyl chains of these fatty acids are long enough to span the entire OM bilayer and if additionally they are covalently linked to the hopanoid residue, they cause an increase in the membrane stability and rigidity (De Castro et al., 2008; Carlson et al., 2010; Silipo et al., 2014).

The outer membrane plays a critical role in the interaction of the bacteria with the environment and in establishment of a symbiotic relationship with leguminous plants. Therefore, we decided to compare Bradyrbizobium and Rhizobium OMs examining their permeability using a fluorescent hydrophobic probe, N-phenyl-1-naphthylamine (NPN), and the OMs resistance to EDTA and polymyxin $\mathrm{B}$.

$\mathrm{N}$-phenyl-naphtylamine is a frequently used probe to study the structure and function of biological membranes (Loh et al., 1984). This probe is a hydrophobic fluorescent compound, which fluoresces weakly in aqueous solutions but strongly when transferred into a hydrophobic environment. Such conditions can be found within bacterial membranes. Polymyxin B is a mixture of nonribosomally synthesized basic lipopeptides produced by Bacillus polymyxa. These molecules contain a heptapeptide ring with a tripeptide tail to which different short fatty acids are attached through an amide bond. Poly- myxin B has antibiotic properties and is active against Gram-negative bacteria. This selective activity is related to its high affinity for lipopolysaccharides, especially for the lipid A-inner core part (Orwa et al., 2001; Zavascki et al., 2007; Mares et al., 2009). The importance of electrostatic interactions between LPS acidic groups and six positively charged 2,4-diaminobutyric acid (DAB) residues as well as hydrophobic interactions of polymyxin B (acyl chain, Phe and Leu) with fatty acids from lipid A are emphasized in descriptions of LPS/polymyxin complexes (Mares et al., 2009). Given these properties, this antibiotic is a useful tool to characterize the integrity of Gram-negative bacteria outer membranes.

In our comparative study, we used six rhizobial strains belonging to five genera within the Rhizobiales order. The selected strains produced lipopolysaccharides with very different structures. Because the entire LPS structure can affect membrane properties, we used the rough and smooth type of $E$. coli as the reference strains.

\section{MATERIALS AND METHODS}

Bacterial strains and growth conditions. The bacterial strains used in this study are listed in Table 1. This table also includes abbreviations of bacterial names used to simplify the text. To provide the optimal growth conditions for bacterial cultures, rhizobial strains were grown in tryptone-yeast (TY) medium (tryptone (5 g), yeast extract $(3 \mathrm{~g}), \mathrm{CaCl}_{2}(0.1 \mathrm{~g})$ per liter of $\left.\mathrm{H}_{2} \mathrm{O}\right)$, Vincent's minimal medium (79CA) (Vincent, 1970), and modified Vincent's medium called LPC (Dr. T. Stepkowski, Warsaw Agriculture University, personal communication), respectively (see Table 1). The LPC medium consisted of mannitol $(1.0 \mathrm{~g})$, sodium succinate $(1.0 \mathrm{~g})$, yeast extract $(0.4 \mathrm{~g}), \mathrm{MgSO}_{4}(0.2 \mathrm{~g}), \mathrm{K}_{2} \mathrm{HPO}_{4}(0.1 \mathrm{~g})$, $\mathrm{CaCl}_{2} \times 6 \mathrm{H}_{2} \mathrm{O}(0.04 \mathrm{~g})$, and $\mathrm{NaCl}(0.05 \mathrm{~g})$ per liter of 
Table 2. The influence of increasing concentrations of polymyxin B on the viability of bacterial strains (crude experimental data). All experiments were done in triplicate and are shown as a mean \pm S.D.

\begin{tabular}{|c|c|c|c|c|c|c|c|c|}
\hline \multirow{2}{*}{$\begin{array}{l}\text { Concen- } \\
\text { tration of } \\
\text { polymyxin } \\
\mathrm{B}[\mathrm{U} / \mathrm{ml}]\end{array}$} & $\begin{array}{c}\text { E. coli } \\
\text { HB } 101\end{array}$ & E. coli ATCC & M. huakuii & S. meliloti & R. leguminosarum & O. lupini & B. elkanii & B. japonicum \\
\hline & \multicolumn{8}{|c|}{ Average cfu \pm S.D. } \\
\hline 0 & $880.0 \pm 19.1$ & $1606.0 \pm 39.0$ & $391.0 \pm 15.1$ & $767.5 \pm 12.0$ & $413.7 \pm 9.0$ & $84.7 \pm 6.1$ & $315.0 \pm 7.9$ & $1580.7 \pm 144.4$ \\
\hline 5 & $0.0 \pm 0.0$ & $185.0 \pm 8.0$ & $256.0 \pm 11.8$ & $654.3 \pm 48.0$ & $404.3 \pm 7.6$ & $88.5 \pm 2.1$ & $312.3 \pm 8.1$ & $1480.7 \pm 15.5$ \\
\hline 10 & $0.0 \pm 0.0$ & $133.0 \pm 4.0$ & $157.7 \pm 5.7$ & $563.0 \pm 28.5$ & $363.3 \pm 16.9$ & $78.0 \pm 14.0$ & $305.5 \pm 3.5$ & $1524.7 \pm 171.9$ \\
\hline 25 & $0.0 \pm 0.0$ & $79.3 \pm 7.5$ & $9.7 \pm 2.1$ & $357.7 \pm 8.0$ & $319.0 \pm 9.0$ & $79.3 \pm 11.9$ & $285.7 \pm 10.1$ & $1531.3 \pm 109.2$ \\
\hline 50 & $0.0 \pm 0.0$ & $35.7 \pm 5.9$ & $2.3 \pm 1.2$ & $103.7 \pm 17.2$ & $255.0 \pm 10.6$ & $69.7 \pm 16.6$ & $215.3 \pm 19.9$ & $1550.7 \pm 98.1$ \\
\hline 75 & $0.0 \pm 0.0$ & $13.7 \pm 3.1$ & $1.3 \pm 0.6$ & $16.3 \pm 5.7$ & $205.0 \pm 15.0$ & $77.0 \pm 5.2$ & $209.0 \pm 25.5$ & $1572.0 \pm 50.5$ \\
\hline 100 & $0.0 \pm 0.0$ & $5.7 \pm 1.5$ & $0.0 \pm 0.0$ & $3.3 \pm 1.5$ & $165.3 \pm 7.2$ & $62.3 \pm 3.1$ & $208.3 \pm 15.5$ & $1520.7 \pm 81.3$ \\
\hline 250 & $0.0 \pm 0.0$ & $0.0 \pm 0.0$ & $0.0 \pm 0.0$ & $0.0 \pm 0.0$ & $51.3 \pm 3.8$ & $55.3 \pm 18.0$ & $213.5 \pm 10.6$ & $1578.7 \pm 96.8$ \\
\hline 500 & $0.0 \pm 0.0$ & $0.0 \pm 0.0$ & $0.0 \pm 0.0$ & $0.0 \pm 0.0$ & $8.3 \pm 1.5$ & $31.0 \pm 2.6$ & $201.7 \pm 3.5$ & $1538.0 \pm 46.1$ \\
\hline 750 & $0.0 \pm 0.0$ & $0.0 \pm 0.0$ & $0.0 \pm 0.0$ & $0.0 \pm 0.0$ & $0.0 \pm 0.0$ & $16.0 \pm 1.7$ & $153.3 \pm 1.2$ & $1586.7 \pm 60.2$ \\
\hline 1000 & $0.0 \pm 0.0$ & $0.0 \pm 0.0$ & $0.0 \pm 0.0$ & $0.0 \pm 0.0$ & $0.0 \pm 0.0$ & $3.7 \pm 2.1$ & $126.7 \pm 8.1$ & $1523,7 \pm 116.7$ \\
\hline
\end{tabular}

$\mathrm{H}_{2} \mathrm{O}$ ( $\mathrm{pH} 7.0-7.2$ ). Rhizobia were cultivated at $28^{\circ} \mathrm{C}$ for $48^{2}$ h. Escherichia coli strains were grown in Luria-Bertani (LB) medium (Sambrook 1989) at $37^{\circ} \mathrm{C}$ for $18 \mathrm{~h}$.

SDS-PAGE. Tricine SDS-PAGE (using 12.5\% acrylamide) of lipopolysaccharide samples obtained from whole-cell lysates digested by Proteinase $\mathrm{K}$ was performed as described (Hitchcock \& Brown, 1983; Lesse et al., 1990). Before analysis, bacterial cells were extensively washed with $0.9 \%$ saline to remove the surface capsular material. The gel was silver-stained (Tsai \& Frash, 1982).

Fluorimetry. Exponentially growing cells were harvested and resuspended in $1 \mathrm{mM}$ KCN-10 $\mathrm{mM}$ HEPES $(\mathrm{pH} \mathrm{7.2)}$ at an optical density (at $600 \mathrm{~nm}$ ) of 0.50 and transferred immediately to 1-cm-diameter quartz cuvettes with four optically clear sides. After 50 seconds, N-phenyl-1-naphthylamine (Sigma, cat. no. 104043; NPN, $500 \mathrm{mM}$ in acetone) was added to a final concentration of $10 \mathrm{mM}$. Polymyxin B (Sigma, cat. no. P1004) and EDTA (Sigma, cat. no. E5134) were added to the cuvettes either before or after NPN addition, at the following final concentrations: EDTA $-5 \mathrm{mM}$, polymyxin $\mathrm{B}-100 \mathrm{U} / \mathrm{ml}$, as described previously in: Martínez de Tejada \& co-workers (1995). Fluorescence was monitored at $25^{\circ} \mathrm{C}$ with a FluoroMax-2 spectrofluorometer (Instruments S.A., Inc., JOBIN YVON/SPEX Division, USA) set as follows: excitation $350 \mathrm{~nm}$; emission 420 $\mathrm{nm}$; slit width $5 \mathrm{~nm}$. The results were expressed in RFU (relative fluorescence units).

Sensitivity to polymyxin $\mathbf{B}$ assay. Bacterial sensitivity was measured as the effect of increasing concentrations of polymyxin B on cell viability. The assay described by Riley \& Robertson (1984) was used with some modifications (Martínez de Tejada et al., 1995). One $\mathrm{mg}$ of Polymyxin B is equivalent of 6000 units. The stock solution of polymyxin B $(2000 \mathrm{U} / \mathrm{ml})$ was prepared in sterile $10 \mathrm{mM}$ PBS ( $\mathrm{pH} 7.0)$, and serial dilutions were made directly in sterile 96-well tissue culture plates using the same buffer as a diluent $(100 \mu \mathrm{l})$ (for final concentrations see Table 2). Bacteria were resuspended in the same buffer solution at approximately $4 \times 10^{4} \mathrm{CFU} /$ $\mathrm{ml}, 100 \mu \mathrm{l}$ of this suspension was dispensed in duplicated series of wells $\left(4 \times 10^{3} \mathrm{CFU}\right.$ per well in $\left.200 \mu \mathrm{l}\right)$, and the plates were incubated for $1 \mathrm{~h}$ at $28^{\circ} \mathrm{C}$ or $37^{\circ} \mathrm{C}$, depending on the bacteria cultivated. Viable counts were performed by spreading $100 \mu \mathrm{l}$ from each well on LPC or LB agar plates, and the results were expressed as the percentage of surviving cells with respect to controls incubated without the antibiotics. Raw experimental data are collected in Table 2 as an average value from three independent experiments and are plotted in Fig. 4. The plots in Fig. 4 were smoothed using polynomial functions from Excel 2013 trend options.

Transmission electron microscopy analysis of bacterial cells. Bacterial cells were prepared for TEM microscopy using modified procedures described by Martínez de Tejada \& co-workers (1995), Velasco \& co-workers (2000), and Palusińska-Szysz \& co-workers (2012). Briefly, after a $20 \mathrm{~min}$. incubation in the presence of polymyxin $\mathrm{B}(20 \mu \mathrm{g} / \mathrm{ml})$ at $28^{\circ} \mathrm{C}$, the bacterial suspensions were centrifuged at $8000 \times g$ for $10 \mathrm{~min}$. The resulting bacterial pellets were used for microscopic analyses. The pelleted bacterial cells exposed to polymyxin B, as well as the control samples, were flooded with PBS buffer (Sigma, cat. no. P4417; pH 7.4) containing $2.5 \%$ glutaraldehyde (GA). Prior to fixation, each culture was mixed with a fixative solution in proportion 2:1 (v/v) for $5 \mathrm{~min}$; then, the cell suspension was centrifuged at $6000 \times g$ for $10 \mathrm{~min}$ at $10^{\circ} \mathrm{C}$. Bacterial pellets were washed with fresh fixative, fixed for $2 \mathrm{~h}$ at $4^{\circ} \mathrm{C}$ in PBS buffered GA (2.5\%), and centrifuged $(6000 \times g$ for 8 min, at $\left.4^{\circ} \mathrm{C}\right)$. Next, the specimens were rinsed twice with PBS and post-fixed in a $1 \%$ osmium tetraoxide solution 


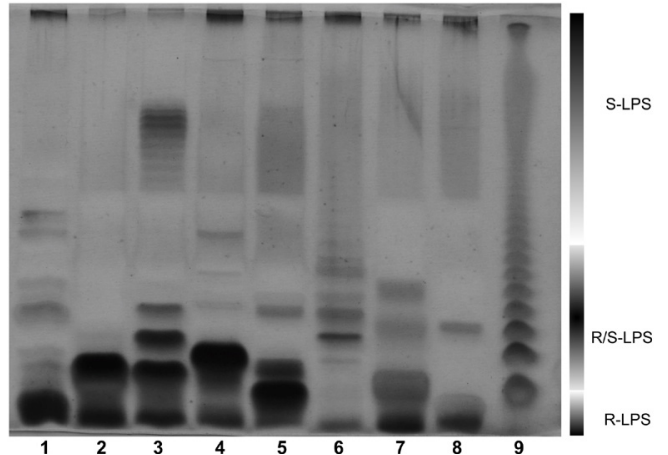

Figure 1. Silver-stained tricine SDS-PAGE gel of lipopolysaccharides from:

lane 1, Rhizobium leguminosarum bv. Trifolii TA1; lane 2, Escherichia coli HB 101; lane 3, Escherichia coli ATCC 25922; lane 4, Mesorhizobium huakuii IFO15243'; lane 5, Ochrobactrum lupini LUP 21 lane 6, Bradyrhizobium japonicum USDA 110; lane 7, Sinorhizobium meliloti 1021; lane 8, Bradyrhizobium elkanii USDA 76; lane 9, Salmonella enterica Sv. Typhimurium (Sigma, cat. no. L6511). The side panel shows approximate ranges of rough $(R)$, semi smooth $(S / R)$, and smooth (S) LPS forms.
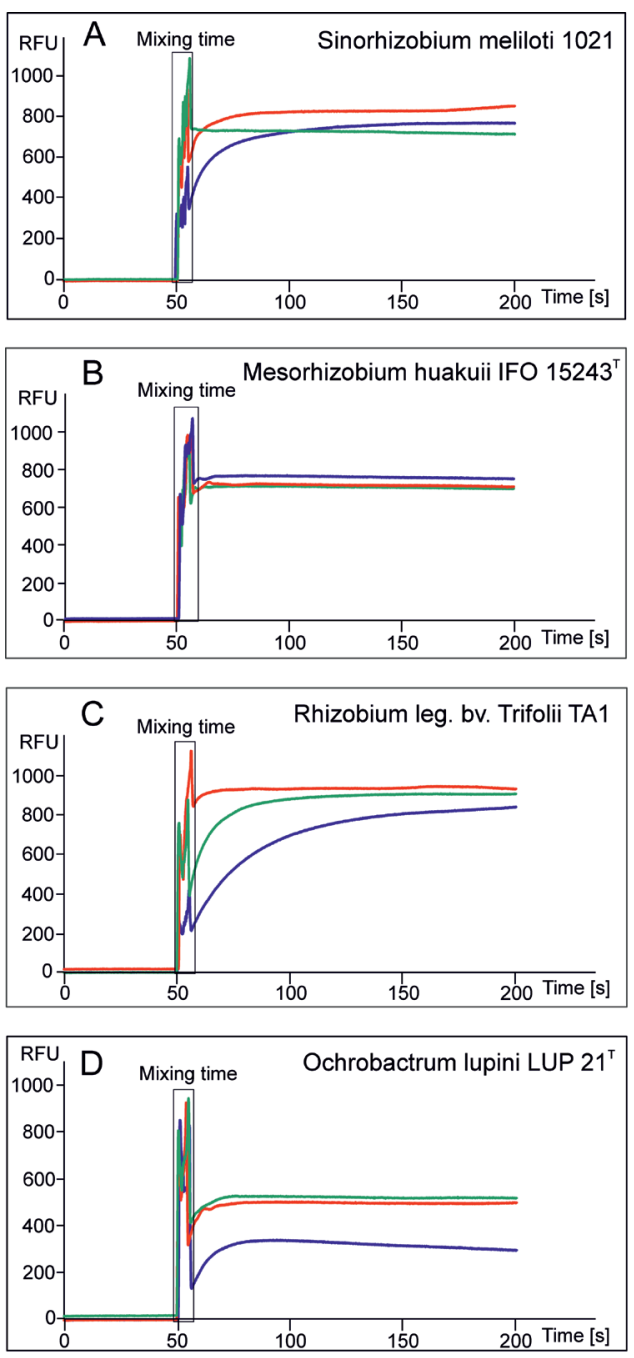

- NPN

in PBS $\left(1.5 \mathrm{~h}\right.$, at $\left.4^{\circ} \mathrm{C}\right)$. After another wash with PBS, the bacteria were stained en bloc in $0.5 \%$ uranyl acetate $(30$ min), dehydrated in a series of alcohol and acetone solutions, and embedded in the LR White resin. Ultrathin sections were cut with a diamond knife using an RMC MT-XL microtome (Boeckeler Instruments, Tucson, AZ, USA), collected on copper grids, and contrasted using uranyl acetate and Reynold's liquid. The samples were observed under a LEO-Zeiss 912 AB electron microscope (Carl Zeiss Microscopy, Oberkohen, Germany).

\section{RESULTS}

Lipopolysaccharides, released from bacterial cells using a micro-method, were compared by SDS-PAGE (Fig. 1). Based on this analysis, the types of LPS (rough $-R$, semi smooth $-S / R$, or smooth $-S$ ) were assessed. A classical ladder-like pattern of LPS mass distribution was observed for the $S$. enterica preparation. In this case, the ladder was stretched from the top to the bottom of the gel and the most abundant region was located in the upper part of the gel. Rhizobium LPS samples possessed more complex patterns. There were many irregu-
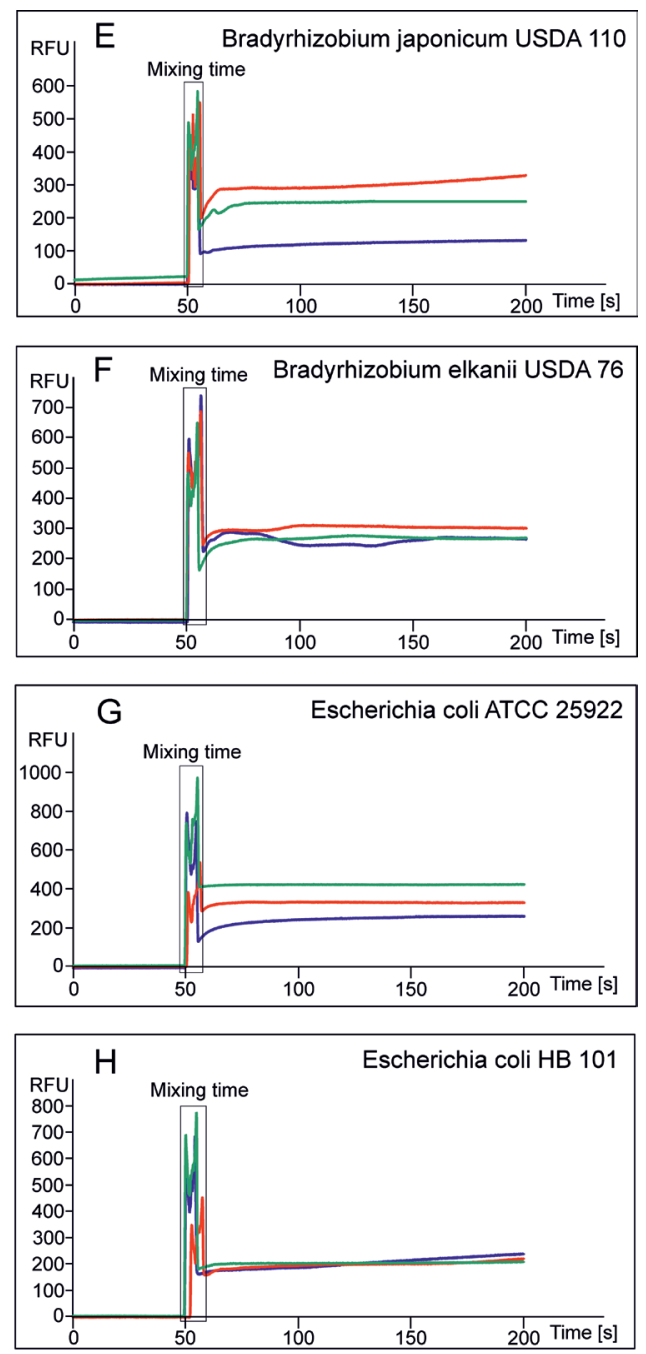

- NPN+PolB

Figure 2. Effects of polymyxin B and EDTA on the incorporation of NPN into the outer membranes of Sinorhizobium meliloti 1021 (A), Mesorhizobium huakuii IFO15243 (B), Rhizobium leguminosarum bv. Trifolii TA1 (C), Ochrobactrum lupini LUP 21T (D), Bradyrhizobium japonicum USDA 110 (E), Bradyrhizobium elkanii USDA 76 (F), Escherichia coli ATCC 25922 (G), and Escherichia coli HB 101 (H).

Green line - incorporation of NPN in the presence of polymyxin B, red line - incorporation of NPN in the presence of EDTA, blue line incorporation of NPN in the absence of membrane-deteriorating agents. 


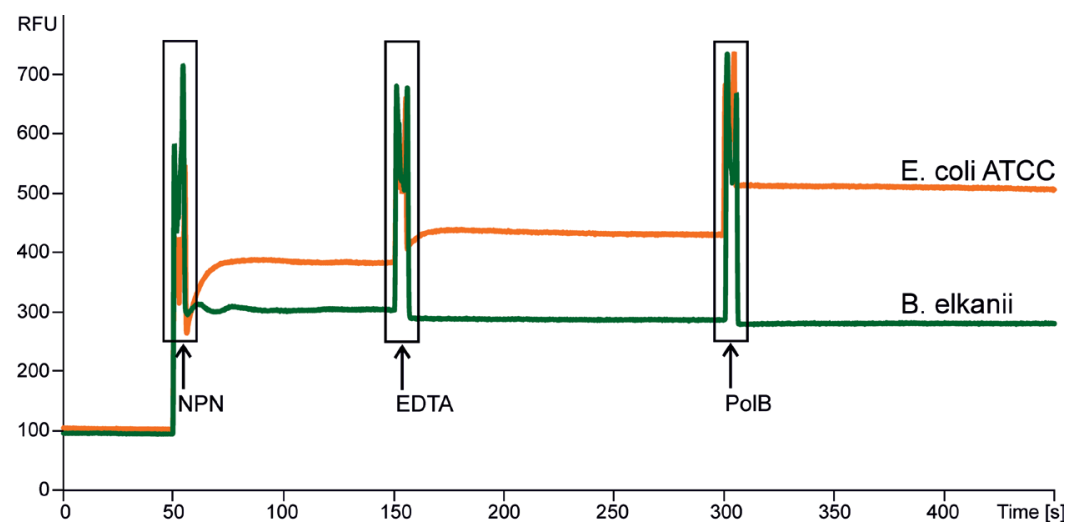

Figure 3. The joint effect of EDTA and polymyxin B action on incorporation of NPN by Escherichia coli ATCC 25922 (orange line) and Bradyrhizobium elkanii USDA 76 (green line).

NPN was added to the bacterial suspension at $50 \mathrm{sec}$ of the experiment, and then at $150 \mathrm{sec}$ EDTA was added, and finally, at $300 \mathrm{sec}$, polymyxin B (PolB) was added. For details, see the Materials and methods section.

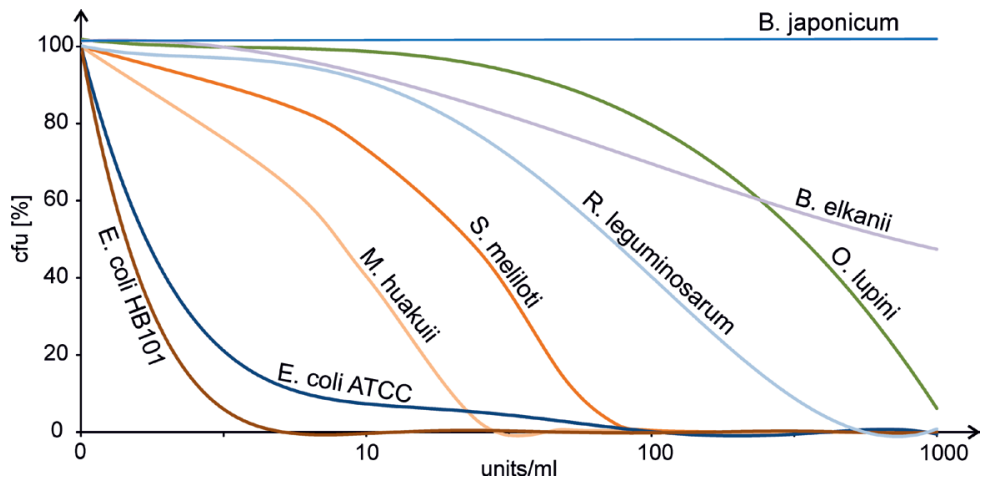

Figure 4. Effects of polymyxin B on the viability of Escherichia coli HB101, Escherichia coli ATCC 29522, Mesorhizobium huakuii IFO $15243^{\top}$, Sinorhizobium meliloti 1021, Rhizobium leguminosarum bv Trifolii, Ochrobactrum lupini LUP21', Bradyrhizobium elkanii USDA 76, and Bradyrhizobium japonicum USDA 110.

larities in these profiles. High quantities of the low molecular mass material (a very intense staining) equivalent of high quantities of the rough fraction of lipopolysaccharides were observed in preparations from $R$. legumionsarum, M. buakuii, O. Iupini, and S. meliloti, as well as E. coli HB101 and E. coli ATCC. Moderate intensity of the lipid A-core fraction was noticed for B. elkanii and B. japonicum strains. The smooth fractions of LPS located in the upper half of the PAGE gel were observed in the case of B. elkanii, S. meliloti, O. lupini, M. buakuii, and E. coli ATCC. Lipopolysaccharides from $R$. leguminosarum, $S$. meliloti, $M$. buakuii, and E. coli ATCC possessed intense stained bands in the middle part of the gel. These intermediate fractions represent incomplete LPS (S/R-LPS) with one or only few repeating units attached and are common for rhizobia (Carlson, 1984; Pac et al., 2015). In the analysis of the SDS-PAGE gel, we took into consideration the fact that the intensity of silver staining of a separated material strongly depends on the susceptibility of its structure to oxidation with sodium periodate (a reagent opening saccharide rings between vicinal diols and leaving two aldehyde groups).

All bacterial strains were tested in terms of their capacity for NPN incorporation into the cell membranes under different experimental conditions (Fig. 2). Generally, NPN readily partitioned into cell envelopes of all tested bacteria, reaching an equilibrium at 50 seconds after mixing this agent with the microorganism suspension. $S$. meliloti and $R$. leguminosarum cells were the only exceptions. In the case of $S$. meliloti, a plateau was observed after 150 seconds and, when R. leguminosarum cells were analyzed, the fluorescence grew exponentially along the entire observation time. Presumably, the spatial structures of the O-polysaccharides are responsible for these effects. However, in both cases, partition equilibrium was reached considerably faster when EDTA or polymyxin B was added (Fig. 2A, C). Both E. coli strains, B. japonicum, B. elkanii, and O. lupini hardly took up any NPN, giving a low level of emission at $450 \mathrm{~nm}$ ( $200 \mathrm{RFU})$. High fluorescence $(\sim 1000 \mathrm{RFU})$ was observed when S. meliloti, $M$. buakuii, or $\mathrm{R}$. leguminosarum cells were treated with the NPN-containing solution. EDTA and polymyxin B substantially facilitated transfer of NPN molecules to the hydrophobic environment of membranes and caused an increase in the fluorescence of B. japonicum, O. lupini, and E. coli ATCC suspensions, when compared with the untreated bacteria (Fig. 2D, E, G). The interaction of the membranes ( $\mathrm{OM}$ and $\mathrm{CM}$ ) with both deteriorating agents resulted in elevation of the fluorescence intensity (Fig. 2D, E, G). However, B. japonicum OM was more susceptible to the EDTA action (Fig. 2E), contrary to E. coli ATCC OM (Fig. 2G), which was more sensitive to polymyxin B. Only the O. Iupini envelope was found to be susceptible to both agents in the same manner (Fig. 2D). The permeability of the cell membranes from S. meliloti, M. buakuii, B. elkeanii, and E. coli HB101 measured by the fluorescence effect was independent of the presence of EDTA or polymyxin B (Fig. 2A, B, F, H). Moreover, in a longer period of observation (about 150 seconds), the same conclusion was true for $\mathrm{R}$. leguminosarum (Fig. 2C). 

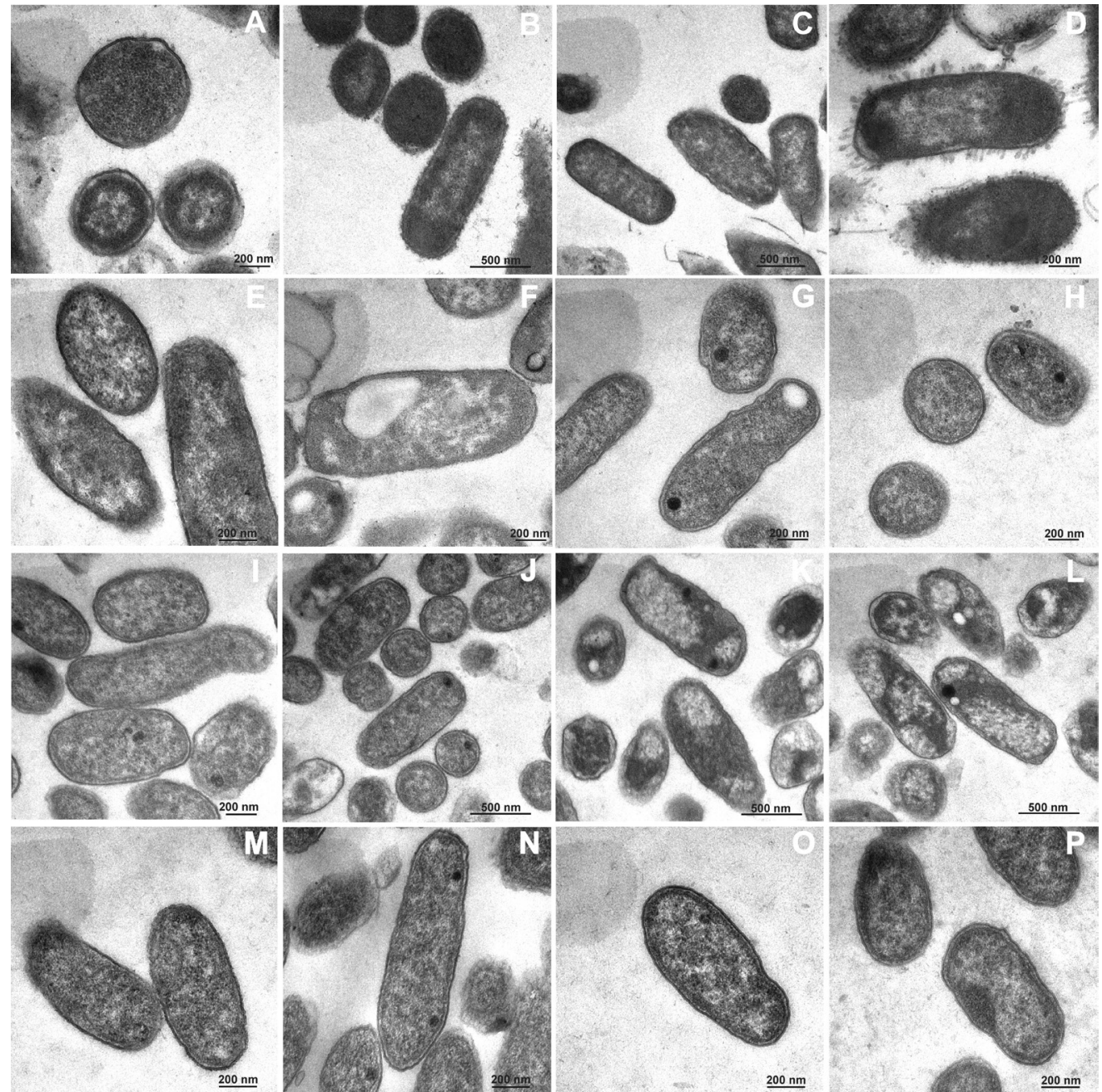

Figure 5. Transmission electron microscope images of bacteria incubated $(20 \mathrm{~min})$ in a medium with polymyxin $B(20 \mu \mathrm{g} / \mathrm{ml})(B, D, F$, $\mathrm{H}, \mathbf{J}, \mathrm{L}, \mathrm{N}, \mathrm{P})$ or without the antibiotic (A, C, E, G, I, K, M, O).

Micrographs of E. coli HB101 (A, B), E. coli ATCC 25922 (C, D), R. leguminosarum bv. Trifolii TA1 (E, F), Sinorhizobium meliloti 1021 (G, H), Ochrobactrum lupini LUP21 $1^{\top}(\mathbf{I}, \mathbf{J})$, Mesorhizobium huakuii IFO $15243^{\top}(\mathbf{K}, \mathbf{L})$, Bradyrhizobium elkanii USDA 76 (M, N), and Bradyrhizobium japonicum USDA 110 (0, P).

The joint action of EDTA and polymyxin B was observed in experiments where, after addition of the NPN to bacterial suspension, the reaction mixture (in a cuvette) was supplemented with EDTA and then with polymyxin B at 150 and 300 seconds, respectively, in the course of an experiment (Fig. 3). The orange colored line shows the course of the experiment when E. coli ATCC cells were used. Addition of EDTA to the suspension elevated fluorescence (in about 10 seconds). Subsequent addition of polymyxin B caused further fluorescence intensification. The same shape of experimental plots, but not as spectacular, was observed when $O$. lupini and B. japonicum cells were studied (data not shown). In a reverse experiment, the increase of fluorescence was observed only after addition of polymyxin B (data not shown). This indicates that polymyxin B can fully destroy the permeability barrier of the outer membrane on its own and further EDTA addition is unnecessary.

The permeability of B. elkanii, M. buakuii, and E. coli HB101 cell membranes to NPN was independent of EDTA and polymyxin B presence. The experiment with the B. elkanii strain shows only a weak effect of dilution of the cell suspension by the added agents, manifested by a slight reduction in fluorescence intensity (Fig. 3, green plot). As mentioned above, the cells of $\mathrm{R}$. legumi- nosarum and $S$. meliloti incorporated NPN slowly and that could be the reason why the action of EDTA together with polymyxin $\mathrm{B}$ was merely visible (data not shown).

The influence of the increasing concentrations of polymyxin $\mathrm{B}$ (from 0 to $1000 \mathrm{U} / \mathrm{ml}$ ) on the viability of the eight investigated strains is illustrated in Fig. 4 and Table 2. This assay indicated that B. japonicum was completely resistant to the antibiotic within the range of the concentrations used. Also, B. elkanii exhibited elevated tolerance to polymyxin B. About $40 \%$ of B. elkanii cells survived a one-hour incubation in the most concentrated $(1000 \mathrm{U} / \mathrm{ml})$ solution of the antibiotic. $O$. lupini can be classified as polymyxin B-resistant bacteria, but the concentration of $1000 \mathrm{U} / \mathrm{ml}$ was bactericidal to them. The effect of polymyxin $B$ on the viability of $R$. leguminosarum, S. meliloti, and $M$. buakuii is illustrated in Fig. 4 by the sigmoidal-shape curves. E. coli strains were the most sensitive to this agent. Moreover, E. coli HB 101, the R-type strain, was found to be the least resistant strain among the investigated bacteria. The estimated bactericidal concentration of the lipopeptide to the $\mathrm{HB}$ 101 strain was lower than $5 \mathrm{U} / \mathrm{ml}$ (Table 2).

To demonstrate how polymyxin $\mathrm{B}$ affects the rhizobial cells, transmission electron microscopy was used. All cells had a typical size of about $1.2 \div 1.6 \mu \mathrm{m}$ in length 
and $0.4 \div 0.6 \mu \mathrm{m}$ in diameter. The TEM micrographs of control cells (E. coli HB101 - Fig. 5A and E. coli ATCC - Fig. 5C), not treated with the antibiotic, revealed bacteria surrounded by well discernible outer and cytoplasm membranes. The OM was always slightly waved. The cytosol of these bacteria was intensely electron-dense with local brighter areas of intracellular DNA concentration. E. coli cells treated with polymyxin B changed dramatically with respect to their wall structure. The peptide antibiotic induced extensive blebbing in the rough- and smooth- type E. coli outer membranes (Fig. 5B and Fig. 5D). This process is well documented in Fig. 5D, where impressive blebbing of E. coli ATCC is presented. This phenomenon was limited only to enterobacterial cells used in our experiment. None of the rhizobium bacteria reacted in a similar manner in response to the presence of polymyxin B in the growth medium. No distortion and/or loss of cell membranes were observed. Moreover, the rhizobial cells exposed to the peptide antibiotic were undistinguishable from the same bacteria but not treated with polymyxin B (used as a control). For instance, in both TEM micrographs of $M$. buakuii, the membranes were found intact; however, electronlucent zones were visible (Fig. 5K and Fig. 5L). Presumably, these places represent empty spaces where PHB granules were located and removed during the dehydration procedure. Some cells presented in Fig. 5 contained black spots (very electron-dense dots) probably representing phosphate granules. They were observed in a series of micrographs (Fig. 5F, 5G, 5H, 5I, 5J, 5L, 5N). Also, in these cases there was no relation between the polymyxin B treated cells and the presence of the listed specific morphological structures. Thus, we can conclude that the tested rhizobia were much more resistant to polymyxin B than the enterobacteria represented in this study by two E. coli strains.

\section{DISCUSSION}

The results of our experiments clearly indicate that the integrity of the rhizobium outer membranes is higher than those of enterobacterial cells. Moreover, rhizobia are covered with envelopes differing in their physicochemical properties.

After treatment of the reference $E$. coli strains with polymyxin $\mathrm{B}$, distinct signs of damage to the cell envelope were detected in the TEM micrographs. Among others, blisters and huge amounts of protruding bubbles were observed. Appearance of such symptoms of bacterial envelope destabilization by cationic peptides has been described previously (Schindler \& Teuber, 1975; Martinez de Tejada et al., 1995; Velasco et al., 2000; Hartmann et al., 2010). For example, outer membrane blebbing was observed in the case of $P$. aeruginosa cells incubated in a medium containing EDTA, polymyxin $\mathrm{B}$, gentamicin, or cationic peptides isolated from macrophages (Sawyer et al., 1988). It is postulated that positively charged polymyxin $\mathrm{B}$ molecules can displace $\mathrm{Ca}^{2+}$ and $\mathrm{Mg}^{2+}$ ions from their sites in the lipopolysaccharide layer and in this way destabilize the OM and then the entire envelope (Zavascki et al., 2007). It was estimated that the chemical affinity of polymyxin B to LPS is twofold higher than that of divalent metal cations. This process leads to penetration of polymyxin B through OM into CM, damaging it and causing cytoplasm leakage to the periplasm and finally formation of many protruded blebs (Wu et al., 1999; Ding et al., 2003; Hartmann et al., 2010). None of the mentioned signs were observed in the micrographs of the rhizobia that were studied here. The cell envelopes of these bacteria treated with polymyxin B were indistinguishable from the non-treated control cells. Polymyxin B was reported to have no effect on Brucella abortus, a human pathogen closely related to rhizobia, in papers of Martinez de Tejada \& co-workers (1995), Manterola \& co-workers (2005), and Velasco \& co-workers (2000). In the latter article mentioned, the pathogenic bacterium $O$. anthropi was also tested for its susceptibility to polymyxin B. Cell envelopes of both of these bacteria were undamaged by this antibiotic; however, it penetrated into the cytoplasm of $O$. anthropi causing coagulation. Our studies, performed on the symbiotic strain O. lupini, did not confirm this phenomenon, although these bacteria are very closely related to $O$. anthropi and both preparations were incubated in solutions containing the same polymyxin $\mathrm{B}$ concentration. The cytoplasm of $O$. lupini seemed to be unaffected by the antibiotic (Fig. 5I, 5J).

All strains with undamaged membranes observed in the TEM experiments were resistant to polymyxin B (Fig. 4). Similar results were obtained in the case of Brucella spp. (Martinez de Tejada et al., 1995). In contrast to Brucella, the simultaneously tested enterobacteria (represented therein by E. coli and $Y$. enterocolitica) were sensitive to polymyxin B. In our experiments, E. coli HB101 with the rough-type LPS was much more susceptible to polymyxin B than the E. coli ATCC containing complete LPS. This phenomenon was described earlier in the work of Martinez de Tejada \& co-workers (1995). No similar correlations were observed in the case of rhizobia. On the contrary, B. elkanii which secreted a moderate amount of the S-form LPS was much more resistant to polymyxin B than M. buakuii, S. meliloti, and O. Iupini bacteria producing a higher than B. elkeanii and similar (among these bacteria) quantity of smooth LPS. We have shown that B. japonicum, producing smooth LPS, was fully resistant to the antibiotic within the range up to 1000 $\mathrm{U} / \mathrm{ml}$. This observation allows a conclusion that, although O-chains play a vital role in bacterial response to polymyxin B, the structure of lipid A as well as the negative net charge in its vicinity seems to be more important. All rhizobia produce completely chemically different types of lipids A from those produced by enterobacteria. Rhizobial lipids A differ in the content and quality of fatty acids and negatively charged groups decorating the core oligosaccharide and the lipid A sugar backbone (Carlson et al., 2010). In the case of rhizobia, intracellular symbionts, and intracellular pathogens, such as Brucella and Legionella, lipid A is highly hydrophobic, mainly because of the presence of the VLCFAs, which can span the OM, providing further stability to this structure. All rhizobia studied to date possess at least one residue of VLCFA within their lipid A and (with the evident exception of Azorbizobium) their negatively charged groups are usually weak acid sugars (i.e., uronic acids and 2-amino2-deoxygluconate). Presumably, carboxylic groups weakly interact with $\gamma$-amino groups of $\mathrm{DAB}$ of polymyxin $\mathrm{B}$. Moreover, it can be postulated that the lipophilic part of this antibiotic hardly intercalates into the rigid membrane stabilized by VLCFA or VLCFA connected with hopanoids (Silipo et al., 2014).

Based on the physico-chemical properties of bacterial $\mathrm{OMs}$ discussed above and the known structures of their main components - lipids A, it is possible to divide bacteria into two groups. The first one comprises bacteria with an enterobacterial type of lipid A. Generally, they have OMs highly sensitive to deteriorating agents. The second group comprises bacteria that can synthetize lipid A modi- 
fied with VLCFAs. This group includes all rhizobia (with the exception of Azorbizobium), as well as pathogens such as Brucella, Ochrobactrum, or Legionella species. This group contains a subgroup of bacteria that are extremely resistant to polycationic antibiotics (in our investigations represented by B. elkanii and B. japonicum). These bacteria are able to produce lipid A with a highly expanded hydrophobic part and weak anionic decorations.

It was clear from the NPN fluorescence tests that the surface of the rhizobial cells were being very moderately modified by membrane-destroying agents to allow uptake of this hydrophobic probe. However, exposure of O. lupini and B. japonicum bacteria to polymyxin B or EDTA caused a distinct elevation of NPN fluorescence; therefore, it can be assumed that in both cases displacement of divalent-cations from their binding sites on the outer leaflets took place and resulted in loosening of the LPS-made hydrophobic barrier. The same conclusion seems to be ineligible regarding other rhizobia where the level of probe fluorescence was irrespective of the membrane-destroying agents.

Another issue is the capacity of OM to absorb NPN. The double-lipid layer of OM of Gram-negative bacteria has an approximately similar volume (hydrophobic space), thus one can expect that the maximum uptake of NPN by bacteria should be comparable. This hypothesis was not proven true by the experiments presented here (see Fig. 2). The amount of incorporated NPN seems to be strain dependent, and in some cases can be modified by external agents (see also: Loh et al., 1984; Martínez de Tejada et al., 1995; Velasco et al., 2000).

Given all the experimental data, it can be postulated that the integrity of the rhizobium $\mathrm{OM}$ is considerably higher than that of the enterobacterial OM. Moreover, electrostatic interactions of divalent-cations with LPS molecules seem to be as important as the hydrophobic forces among the membrane-forming fatty acids. A particular role in maintaining stability is ascribed to VLCFAs and hopanoids, being independent components of OM as well as integral elements of bradyrhizobial lipids A.

Despite the above conclusions, it is necessary to emphasize that there is no direct and simple answer to the question why rhizobial cells differ in their sensitivity/ resistance to polymyxin B and why their cell envelopes differ so much in response to a hydrophobic probe (NPN). The answer must cover many aspects of individual membrane components (OM proteins, lipid anchored polysaccharides, the presence of cations, and so on) as well as entire individual LPS structures. It should be highlighted that completely different OM structures and different resistance to deteriorating agents do not affect the abilities of rhizobia to penetrate legume tissues and colonize the developed nodules. However, the method used here is simple and effective in showing differences among bacterial OMs.

\section{Acknowledgements}

Authors thank Ms. Joanna Zalewska (Dept. of Genetics and Microbiology, UMCS) for performing the SDSPAGE analysis.

This work was supported by the Polish Ministry of Science and Higher Education, grant number: N N303 822840 and the BS/UMCS research program.

\section{REFERENCES}

Bhat UR, Carlson RW, Busch M, Mayer H (1991a) Distribution and phylogenetic significance of 27 -hydroxy-octacosanoic acid in lipopolysaccharides from bacteria belonging to the alpha-2 subgroup of Proteobacteria. Int J Syst Bacteriol 41: 213-217.
Bhat UR, Forsberg LS, Carlson RW (1994) Structure of lipid A component of Rhizobium leguminosarum bv. phaseoli lipopolysaccharide. J Biol Chem 269:14402-14410.

Bhat UR, Mayer H, Yokota A, Hollingsworth RI, Carlson RW (1991b) Occurrence of lipid A variants with 27-hydroxyoctacosanoic acid in lipopolysaccharides from members of the family Rhizobiaceae. J Bacteriol 173: 2155-2159.

Carlson RW, Forsberg LS, Kannenberg EL (2010) Lipopolysaccharides in Rhizobium-legume symbioses. Subcell Biochem 53: 339-386. http:// dx.doi:10.1007/978-90-481-9078-2_16.

Carlson RW (1984) Heterogeneity of Rbizobium lipopolysaccharides. I Bacteriol 158: 1012-1017.

Chen WX, Li GS, Qi YL, Wang ET, Li JL (1991) Rhizobium buakuii sp. nov. isolated from the root nodules of Astragalus sinicus. Int I Syst Bacteriol 41: 275-280.

Choma A, Komaniecka I, Turska-Szewczuk A, Danikiewicz W, Spolnik G (2012) Structure of lipid A from a stem-nodulating bacterium Azorbizobium caulinodans. Carbohydr Res 352: 126-136. http://dx.doi. org/10.1016/j.carres.2012.03.003.

Choma A, Komaniecka I (2011) Straight and branched $\omega-1$ hydroxylated very long chain fatty acids are components of Bradyrbizobium lipid A. Acta Biochim Pol 58: 51-57. www.actabp.pl/pdf/1_2011/51.

Choma A, Sowinski P, Mayer H (2000) Structure of the O-specific polysaccharide of Mesorbizobium huakuii IFO15243' . Carbobydr Res 329: 459-464.

Choma A, Sowiński P (2004) Characterization of Mesorbizobium buakuii lipid A containing both D-galacturonic acid and phosphate residues. Eur J Biochem 271: 1310-1322. http://dx.doi.org/10.1111/j.14321033.2004.04038.x.

De Castro C, Molinaro A, Lanzetta R, Silipo A, Parrilli M (2008) Lipopolysaccharide structures from Agrobacterium and Rhizobiaceae species. Carbohydr Res 343: 1924-1933. http://dx.doi.org/10.1016/j. carres.2008.01.036.

Delamuta JR, Ribeiro RA, Ormeño-Orrillo E, Melo IS, Martínez-Romero E, Hungria M (2013) Polyphasic evidence supporting the reclassification of Bradyrbizobium japonicum group Ia strains as Bradyrhizobium diazoefficiens sp. nov. Int J Syst Evol Microbiol 63: 3342-3351. http://dx.doi.org/10.1099/ijs.0.049130-0.

Ding L, Yang L, Weiss TM, Waring AJ, Lehrer RI, Huang HW (2003) Interaction of antimicrobial peptides with lipopolysaccharides. Biochemistry 42: 12251-12259. http://dx.doi.org/10.1021/bi035130.

Gil-Serrano AM, Gonzalez-Jimenez I, Tejero-Mateo P, Megias M, Romero-Vazquez MJ (1994) Analysis of the lipid moiety of lipopolysaccharide from Rhizobium tropici CIAT899: Identification of 29-hydroxytriacontanoic acid. J Bacteriol 176: 2454-2457.

Gudlavalletti SK, Forsberg LS (2003) Structural characterization of the lipid A component of Sinorbizobium sp. NGR234 rough and smooth form lipopolysaccharide. J Biol Chem 278: 3957-3968. http://dx.doi. org/10.1074/ibc.M210491200.

Hartmann M, Berditsch M, Hawecker J, Ardakani MF, Gerthsen D, Ulrich AS (2010) Damage of the bacterial cell envelope by antimicrobial peptides gramicidin S and PGLa as revealed by transmission and scanning electron microscopy. Antimicrob Agents Chemother 54: 3132-3142. http://dx.doi.org/10.1128/AAC.00124-10.

Hitchcock PJ, Brown TM (1983) Morphological heterogeneity among Salmonella lipopolysaccharide chemotypes in silver-stained polyacrylamide gels. I Bacteriol 154: 269-277.

Jordan DC (1982) Transfer of Rhizobium japonicum Buchanan 1980 to Bradyrhizobium gen. nov., a genus of slow-growing root nodule bacteria from leguminous plants. Int J Syst Bacteriol 32: 136-139.

Kannenberg EL, Carlson RW (2001) Lipid A and O-chain modifications cause Rhizobium lipopolysaccharides to become hydrophobic during bacteroid development. Mol Microbiol 39: 379-391. http:// dx.doi.org/10.1046/j.1365-2958.2001.02225.

Komaniecka I, Choma A, Lindner B, Holst O (2010) The structure of a novel neutral lipid A from the lipopolysaccharide of Bradyrbizobium elkanii containing three mannoses units in the backbone. Chem Eur I 16: 2922-2929. http://dx.doi.org/10.1002/chem.200902390.

Komaniecka I, Choma A, Mazur A, Duda KA, Lindner B, Schwudke D, Holst O (2014) Occurrence of an unusual hopanoid-containing lipid A among lipopolysaccharides from Bradyrbizobium species. J Biol Chem 289: 35644-35655. http://dx.doi.org/10.1074/jbc. M114.614529.

Kuykendall LD, Saxena B, Devine TE, Udell SE (1992) Genetic diversity in Bradyrbizobium japonicum Jordan 1982 and a proposal for Bradyrbizobium elkanii sp. nov. Can J Microbiol 38: 501-505. http:// dx.doi.org/10.1139/m92-082.

Lesse AJ, Campagnari AA, Bittner WE, Apicella MA (1990) Increased resolution of lipopolysaccharides and lipooligosaccharides utilizing tricine-sodium dodecyl sulfate-polyacrylamide gel electrophoresis. I Immnol Methods 126: 109-117. http://dx.doi.org/10.1016/00221759(90)90018-Q.

Loh B, Grant C, Hancock REW (1984) Use of the fluorescent probe 1-N-phenylnaphthylamine to study the interactions of aminoglycoside antibiotics with the outer membrane of Pseudomonas aeruginosa. Antimicrob Agents Chemother 26: 546-551. 
Manterola L, Moriyón I, Moreno E, Sola-Landa A, Weiss DS, Koch MHJ, Howe J, Brandenburg K, López-Goñi I (2005) The lipopolysaccharide of Brucella abortus BvrS/BvrR mutants contains lipid A modifications and has higher affinity for bactericidal cationic peptides. J Bacteriol 187: 5631-5639. http://dx.doi.org/ 10.1128/ JB.187.16.5631-5639.2005.

Mares J, Kumaran S, Gobbo M, Zerbe O (2009) Interactions of lipopolysaccharide and polymyxin studied by NMR spectroscopy. J Biol Chem 284: 11498-11506. http://dx.doi.org/10.1074/jbc. M806587200.

Martínez de Tejada G, Pizarro-Cerdá J, Moreno E, Moriyón I (1995) The outer membranes of Brucella spp. are resistant to bactericidal cationic peptides. Infect Immun 3: 3054-3061.

Meade HM, Long SR, Ruvkun GB, Brown SE, Ausubel FM (1982) Physical and genetic characterization of symbiotic and auxotrophic mutants of Rhizobium meliloti induced by transposon Tn5 mutagenesis. J Bacteriol 149: 114-122.

Muszynski A, Laus M, Kijne JW, Carlson RW (2011) Structures of the lipopolysaccharides from Rhizobium leguminosarum RBL5523 and its UDP-glucose dehydrogenase mutant (exo5). Glycobiology 21: 5568. http://dx.doi.org/10.1093/glycob/cwq131.

Nikaido H (2003) Molecular basis of bacterial outer membrane permeability revisited. Microbiol Mol Biol Rev 67: 593-656. http://dx.doi. org/10.1128/MMBR.67.4.593-656.2003.

Orwa JA, Govaerts C, Busson R, Roets E, Van Schepdael A, Hoogmartens J (2001) Isolation and structural characterization of polymyxin B components. J Chromatogr A 912: 369-373. http://dx.doi. org/10.1016/S0021-9673(01)00585-4.

Pac M, Komaniecka I, Zamlynska K, Turska-Szewczuk A, Choma A (2015) Structure of the O-specific polysaccharide from the legume endosymbiotic bacterium Ochrobactrum cytisi strain ESC1 ${ }^{\mathrm{T}}$. Carbohydr Res 413: 37-40. http://dx.doi.org/10.1016/j.carres.2015.05.002

Palusińska-Szysz M, Zdybicka-Barabas A, Pawlikowska-Pawlęga B, Mak P, Cytryńska M (2012) Anti-Legionella dumoffii activity of Galleria mellonella defensin and apolipophorin III. Int J Mol Sci 13: 17048-17064. http://dx.doi.org/10.3390/ijms131217048.

Que NLS, Lin S, Cotter RJ, Raetz CRH (2000) Purification and mass spectrometry of six lipid A species from the bacterial endosymbiont Rbizobium etli. J Biol Chem 275: 28006-28016. http://dx.doi. org/10.1074/jbc.M004008200.

Raetz CRH, Whitfield C (2002) Lipopolysaccharide endotoxins. Annu Rev Biochem 71: 635-700. http://dx.doi.org/10.1146/annurev.biochem.71.110601.135414

Riley LK, Robertson DC (1984) Brucellacidal activity of human and bovine polymorphonuclear leukocyte granule extracts against smooth and rough strains of Brucella abortus. Infect Immun 46: 231236.

Russa R, Urbanik-Sypniewska T, Lindström K, Mayer H (1995) Chemical characterization of two lipopolysaccharide species isolated from Rhizobium loti NZP2213. Arch Microbiol 163: 345-351.
Sambrook J, Fritsch EF, Maniatis T (1989) Molecular cloning: a laboratory manual. 2nd ed. Cold Spring Harbor Laboratory, Cold Spring Harbor, New York.

Sawyer JG, Martin NL, Hancock REW (1988) Interaction of macrophage cationic proteins with the outer membrane of Pseudomonas aeruginosa. Infect Immun 56: 693-698.

Schindler PR, Teuber M (1975) Action of polymyxin B on bacterial membranes: morphological changes in the cytoplasm and in the outer membrane of Salmonella typhimurium and Escherichia coli B. Antimicrob Agents Chemother 8: 95-104.

Silipo A, Vitiello G, Gully D, Sturiale L, Chaintreuil C, Fardoux J, Gargani D, Lee HI, Kulkarni G, Busset N, Marchetti R, Palmigiano A, Moll H, Engel R, Lanzetta R, Paduano L, Parrilli M, Chang WS, Holst O, Newman DK, Garozzo D, D’Errico G, Giraud E, Molinaro A (2014) Covalently linked hopanoid-lipid A improves outermembrane resistance of a Bradyrbizobium symbiont of legumes. Nat Commun 5: 5106. http://dx.doi.org/10.1038/ncomms6106

Triplett EW (1988) Isolation of genes involved in nodulation competitiveness from Rhizobium leguminosarum bv. trifolii T24. Proc Natl Acad Sci USA 85: 3810-3814.

Trujillo ME, Willems A, Abril A, Planchuelo A-M, Rivas R, Ludena D, Mateos PF, Martinez-Molina E, Velazquez E (2005) Nodulation of Lupinus albus by strains of Ochrobactrum lupini sp. nov. Appl Environ Microbiol 71: 1318-1327. [Erratum: Appl Environ Microbiol, 2006, 72(6):4500]. http://dx.doi.org/10.1128/AEM.71.3.1318-1327.2005.

Tsai CM, Frasch CE (1982) A sensitive silver stain for detecting lipopolysaccharides in polyacrylamide gels. Anal Microbiol 119: 115119. http://dx.doi.org/10.1016/0003-2697(82)90673-X.

Vaara M (1992) Agents that increase the permeability of the outer membrane. Microbiol Rev 56: 395-411.

Velasco J, Bengoechea JA, Brandenburg K, Lindner B, Seydel U, González D, Zähringer U, Moreno E, Moriyón I (2000) Brucella abortus and its closest phylogenetic relative, Ochrobactrum spp., differ in outer membrane permeability and cationic peptide resistance. Infect Immun 68: 3210-3218.

Vincent JM (1970) A manual for the practical study of root-nodule bacteria. International biological program handbook no. 15. Blackwell Scientific Publications Ltd, Oxford.

Wu M, Maier E, Benz R, Hancock RE (1999) Mechanism of interaction of different classes of cationic antimicrobial peptides with planar bilayers and with the cytoplasmic membrane of Escherichia coli. Biochemistry 38: 7235-7242. http://dx.doi.org/10.1021/bi9826299.

Zähringer U, Lindner B, Rietschel Eth (1999) Chemical structure of lipid A: recent advances in structural analysis of biologically active molecules. In Endotoxin in Health and Disease Brade H, Opal SM, Vogel SN, Morrison DC eds, pp 93-114. Marcel Dekker, New York.

Zavascki AP, Goldani LZ, Li J, Nation RL (2007) Polymyxin B for the treatment of multidrug-resistant pathogens: a critical review. J Antimicrob Chemother 60: 1206-1215. http://dx.doi.org/10.1093/jac/ $\mathrm{dkm} 357$. 